\title{
The effect of 2 different surgical methods on intracompartmental pressure value in tibial shaft fracture: An experimental study in a rabbit model
}

\author{
Cemil Ertürk, M.D., ${ }^{1 *}$ Mehmet Akif Altay, M.D., ${ }^{1}$ Nuray Altay, M.D., ${ }^{2}$ İbrahim Avşin Öztürk, M.D., ${ }^{1}$ \\ İslam Baykara, M.D., ${ }^{1}$ Cemil Sert, M.D., ${ }^{3}$ Uğur Erdem Işıkan, M.D. ${ }^{1}$
}

\begin{abstract}
'Department of Orthopedics and Traumatology, Harran University Faculty of Medicine, Şanlıurfa-Turkey ${ }^{2}$ Department of Anesthesiology and Reanimation, Harran University Faculty of Medicine, Şanlıurfa-Turkey ${ }^{3}$ Department of Biophysics, Harran University Faculty of Medicine, Şanlıurfa-Turkey
\end{abstract}

\begin{abstract}
BACKGROUND: Intracompartmental pressure (ICP) monitoring is a widely used modality, particularly after intramedullary nailing of tibial shaft fractures. It was hypothesized that ICP value in fracture fixed with llizarov circular fixator (ICF) might be lower than in fracture fixed with intramedullary pin (IMP). The present study is a comparison of ICP value in tibial fractures in a rabbit model fixed with ICF and IMP.
\end{abstract}

METHODS: Twenty male New Zealand White rabbits were randomly divided into 2 groups of equal size: ICF group (Group I) and IMP group (Group 2). Under anesthesia, half of proximal part of the right tibia of all rabbits was fractured. Tibial fractures were fixed with ICF in Group I and IMP in Group 2. ICP values were monitored at 6-hour intervals for 48 hours.

RESULTS: There was statistically significant difference in ICP value between groups $(p<0.00 \mathrm{I})$. While there was statistically significant increase in ICP values 24 hours post surgery, there was statistically significant decrease during second 24 hours following surgery. Most importantly, ICP values of ICF group were significantly lower than those of IMP group at 30, 36, and 42 hours post surgery ( $<<0.05$ ).

CONCLUSION: At $24^{\text {th }}$ hour after fixation, ICP values measured in ICF group were lower compared with those of IMP group. These results indicate that use of ICF in tibial fractures provides additional decompression in the anterior compartment. In light of these findings, ICF may be preferable for treatment of tibial fractures with high risk for compartment syndrome.

Keywords: Acute compartment syndrome; llizarov external fixator; intracompartmental pressure monitoring; intramedullary pin fixation; tibial fractures.

\section{INTRODUCTION}

Acute compartment syndrome (ACS) is a common and well-recognized complication after tibial bone fracture. ${ }^{[1-6]}$ Development of ACS may be related to treatment modal-

"Yazarın şimdiki kurumu: İstanbul Sağlık Bilimleri Üniversitesi Kanuni Sultan Süleyman Eğitim ve Araştırma Hastanesi, İstanbul.

Address for correspondence: Cemil Ertürk, M.D.

İstanbul Sağlık Bilimleri Üniversitesi Kanuni Sultan Süleyman Eğitim ve Araştırma Hastanesi, Ortopedi ve Travmatoloji Anabilim Dalı, Küçükçekmece, İstanbul, Turkey

Tel: +90 212 - 4041500 E-mail: erturkc@yahoo.com

Qucik Response Code

Ulus Travma Acil Cerrahi Derg 2017;23(2):85-90

doi: $10.5505 /$ tjtes.2016.82177

Copyright 2017

TJTES ity employed or nature of tibial fracture. Diagnosis of ACS is difficult and is often achieved using combination of clinical findings and measurements of intracompartmental pressure (ICP). ${ }^{[3]}$

There are numerous surgical methods for treatment of tibia shaft fracture, such as intramedullary nailing or pinning (IMP), external fixation, open reduction, and internal fixation (plating).$^{[7-9]}$ Although intramedullary nailing is considered optimal method of treatment for closed tibial shaft fracture, external fixation may be indicated for patients with unstable closed fracture or fracture complicated by compartment syndrome. [5] Tensioned-wire external fixators, especially llizarov circular fixator (ICF), have been used most frequently for segmental fractures and diaphyseal fractures with periarticular extension. ${ }^{[5,10]}$ Intramedullary nailing is suitable method to achieve acceptable alignment and rigid fixation of tibial diaphyseal fractures. ${ }^{\left[{ }^{[I]}\right.}$ Nail can be inserted percutaneously, causing 
minimal morbidity and without disrupting the fracture hematoma. ICF also provides opportunity for closed reduction and repositioning of bone fragments, and causes minimal disruption of soft tissues in region of fracture with preservation of blood supply. ${ }^{[5,12,13]}$ Both methods are suitable for early use and weight-bearing on the limbs, and neither compromises bone biology.

ACS after intramedullary reamed or unreamed nailing of tibial diaphyseal fracture has been reported in several studies..$^{[9,14-19]}$ According to these articles, ACS can develop as complication of closed intramedullary nailing secondary to traction, manipulation, or reaming. In addition, it was reported in a recent study that ACS can also develop in pediatric tibial shaft fracture treated with flexible IMP. ${ }^{[20]}$ Clinical observation has demonstrated that edema in tibial shaft fracture dissolves day after treatment with ICF; however there is no study investigating ICP measurements after application of ICF for tibial shaft fracture. ICP monitoring after IMP in such fracture has been well documented. Data suggested hypothesis that ICP values in tibial fracture fixed with ICF might be lower than those in fracture fixed with IMP. The aim of the present study was to evaluate ICP values of these 2 commonly used surgical methods (ICF and IMP) in treatment of tibia shaft fracture in rabbit model.

\section{MATERIALS AND METHODS}

Total of 20 6-month-old, male New Zealand White rabbits weighing 2.5 to $3.0 \mathrm{~kg}$ each were used for the present study. Approval was granted by the Harran University animal research ethics committee and study was performed according to guidelines of the Association for Assessment and Accreditation of Laboratory Animal Care.

\section{FractureInjuryProcedureandSurgeryTechnique}

Before initiating injury-inducing procedure, each rabbit was anesthetized with intramuscular injection of combination 5 $\mathrm{mg} / \mathrm{kg}$ xylazine hydrochloride and $50 \mathrm{mg} / \mathrm{kg}$ ketamine hydrochloride administered by an anesthesiologist as previously described. ${ }^{[2]]}$ In addition, $20 \mathrm{mg} / \mathrm{kg} /$ day cefazolin sodium was administered prior to surgery and maintained until $48^{\text {th }}$ hour after injury. Animals were randomly selected and divided into ICF group (Group I; $n=10$ ) and IMP group (Group 2; $n=10)$. After shaving appropriate area, half of proximal part of the right tibia of each rabbit was exposed and tibial bone fracture was performed using custom-made device to create injury similar to standard injury pattern as described in our previous study (Fig. Ia, b). ${ }^{[22]}$ This method creates uniform type of fracture in all subjects with $2.5-\mathrm{kg}$ weight released free-fall from height of $30 \mathrm{~cm}$. In Group I, after closed reduction of the fractured tibia, pre-constructed ICF was applied to the right tibia. Circular external frame composed of $25 / 8 \mathrm{C}$ rings 40 to $45 \mathrm{~mm}$ in diameter was fixed to metaphysis of the tibia proximal to fracture site and diaphysis distal

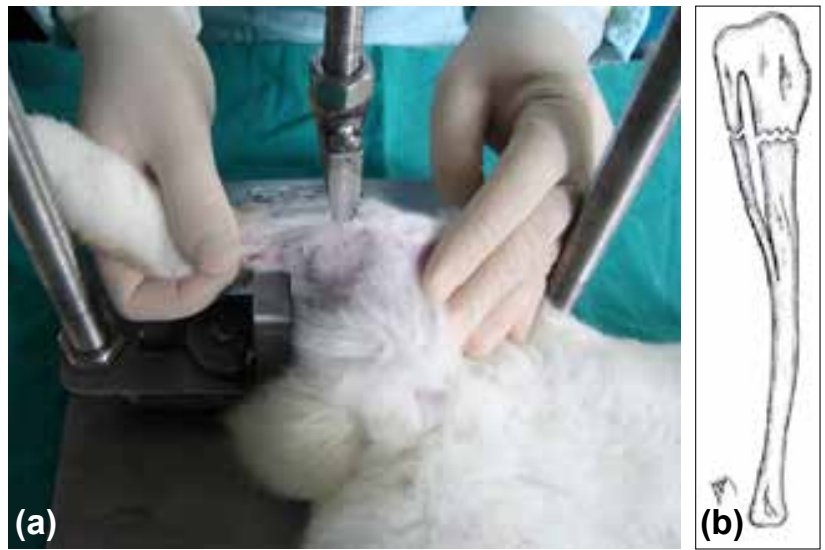

Figure 1. (a) Placement of right tibia on the apparatus. (b) Diagrammatic representation of the fracture.

to fracture site as previously described. ${ }^{[23]}$ Frame was fixed to the tibia with $2 \mathrm{~K}$-wires $\mathrm{I} \mathrm{mm}$ in diameter inserted at $45^{\circ}$ to $60^{\circ}$ angle to one another. Tension was applied to wires at force of 30 to $35 \mathrm{~N}$ (Fig. 2). In Group 2, the fractured tibias were fixed with single 2-mm K-wire at intramedullary location in closed fashion with stab incision at level of tibial tuberosity. Upper end of K-wire was cut to appropriate length and buried.

Intramuscular injection of tramadol $(1 \mathrm{mg} / \mathrm{kg}$ ) was administered for post-procedure pain relief. All animals were kept in separate cages under standard environmental conditions with free access to water and food. Rabbits were maintained in the above-mentioned care conditions and followed-up for 6 weeks to allow for adequate fracture healing before being released to farm environment.

\section{Measurement of Compartmental Pressure}

Side-ported needle was connected to ICP monitoring system (Stryker Intra-Compartmental Pressure Monitor; Stryker Corp., Kalamazoo, MI, USA), which consists of recording box, switch, numerical display, single-use pre-filled syringe of physiological saline, and pressure transmitter. ICP monitoring of

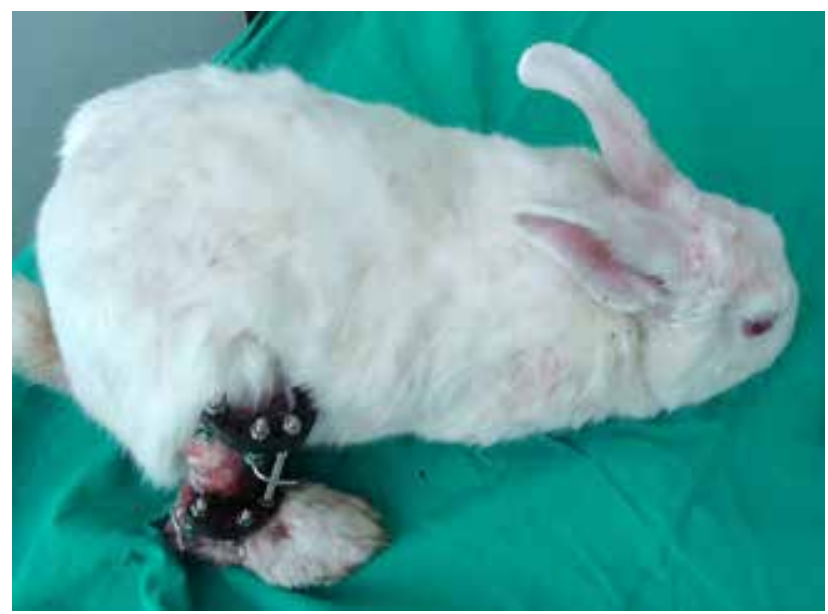

Figure 2. Circular external fixator applied to the fractured tibia. 

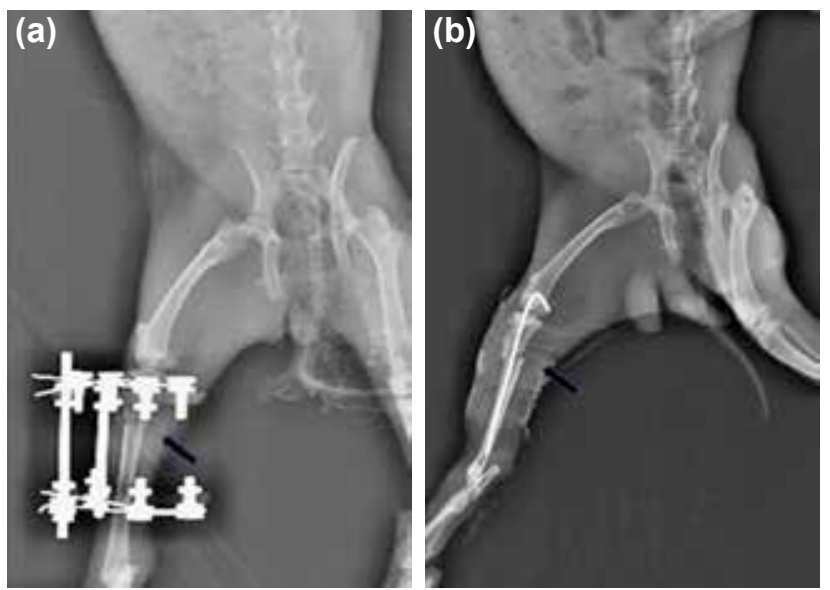

Figure 3. (a) Roentgenogram of fracture just after application of circular external fixator (black arrow). (b) Roentgenogram of fracture just after application of intramedullary pin fixation (black arrow)

anterior tibial compartments of affected tibias was initiated immediately before and after injury, and was performed at 6-hour intervals until $48^{\text {th }}$ hour post injury.

\section{Radiological Analysis}

Anteroposterior radiographs of affected tibias were taken with $52 \mathrm{kV}$ tube voltage and $4.10 \mathrm{~mA}$ tube current just before and after fixation (Fig. 3a, b) as well as at the end of the 6-week follow-up period to confirm fracture position and adequate healing. All radiographs were evaluated by a radiologist.

\section{Statistical Analysis}

Statistical analyses were performed using SPSS software (version 20; IBM Corp., Armonk, NY, USA). Continuous variables were expressed as mediantinterquartile range. MannWhitney $U$ test was used to compare groups. Continuous

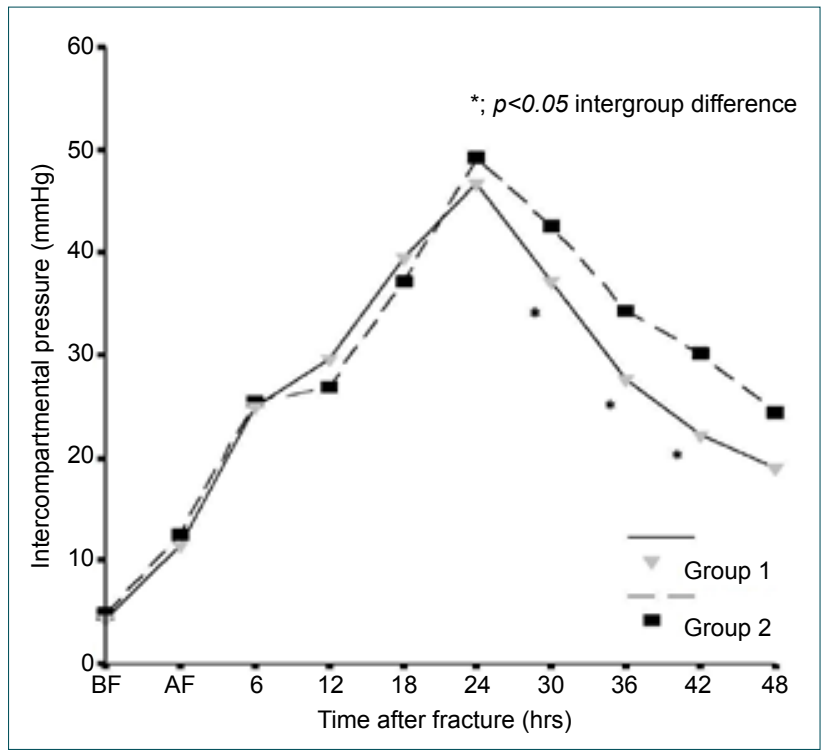

Figure 4. Intracompartmental pressure profiles of rabbits in Groups 1 and 2.

variables were compared using repeated measurement of variance analysis and post hoc Bonferroni test within each group. Two-tailed $p$ value of $<0.05$ was considered to indicate statistical significance.

\section{RESULTS}

All rabbits showed good general health without any sign of discomfort and completed the study uneventfully. They were capable of partial weight-bearing following initial post-injury period.

ICP monitoring results for experimental groups are summarized in Table I. ICP profiles of groups during follow-up

Table I. Median intracompartmental pressure values of each group at each time point

\begin{tabular}{|c|c|c|c|}
\hline \multirow[b]{2}{*}{ Time after fracture (h) } & \multicolumn{2}{|c|}{ Median intracompartmental pressure in $\mathrm{mmHg}$ (Interquartile range) } & \multirow[t]{2}{*}{$\mathbf{p}^{*}$} \\
\hline & $\begin{array}{c}\text { Group I } \\
\text { (Fixed circular external fixator) }\end{array}$ & $\begin{array}{c}\text { Group } 2 \\
\text { (Fixed intramedullary pin) }\end{array}$ & \\
\hline Before fracture & $4.0(3.0)$ & $4.5(2.7)$ & 0.631 \\
\hline Just after fracture & $10.5(4.0)$ & $11.0(4.7)$ & 0.481 \\
\hline $6 \mathrm{~h}$ after fracture & $25.0(5.7)$ & $26.0(9.2)$ & 0.739 \\
\hline $12 \mathrm{~h}$ after fracture & $30.0(12.0)$ & $25.0(8.0)$ & 0.481 \\
\hline $18 \mathrm{~h}$ after fracture & $38.0(5.2)$ & $36.0(8.7)$ & 0.315 \\
\hline $24 \mathrm{~h}$ after fracture & $46.5(7.0)$ & $51.0(9.5)$ & 0.280 \\
\hline $30 \mathrm{~h}$ after fracture & $36.5(7.0)$ & $43.0(6.2)$ & 0.023 \\
\hline $36 \mathrm{~h}$ after fracture & $28.0(10.5)$ & $36.0(11.0)$ & 0.029 \\
\hline $42 \mathrm{~h}$ after fracture & $21.5(8.5)$ & $31.0(12.5)$ & 0.043 \\
\hline $48 \mathrm{~h}$ after fracture & $19.0(7.2)$ & $24.5(9.0)$ & 0.075 \\
\hline
\end{tabular}

*Mann-Whitney $U$ test. 
period are displayed in Figure 4. There was statistically significant difference in ICP values between groups $(p<0.001)$. In both groups, measured ICP values at postoperative $24^{\text {th }}$ hour revealed statistically significant increase. There was also statistically significant decrease in ICP values during second 24 hours post surgery in both groups. Most importantly, ICP values of ICF group were significantly lower compared with values obtained in IMP group at postoperative $30^{\text {th }}, 36^{\text {th }}$, and $42^{\text {nd }}$ hours $(p<0.05)$.

Radiological analyses revealed healing of proximal tibial fractures with similar physiological alignment pattern in all 20 animals during initial postoperative period, and all fractures were determined to be completely healed within 6 weeks.

\section{DISCUSSION}

Most important finding of the present study is that ICP values of ICF group were significantly lower than those of IMP group at $30^{\text {th }}, 36^{\text {th }}$, and $42^{\text {nd }}$ postoperative hour. In both groups, measured ICP values at postoperative $24^{\text {th }}$ hour were found to be significantly increased. There was also statistically significant decrease in ICP during second 24 hours post surgery in both groups. To our knowledge, this is the first study comparing ICP profiles of tibial fractures with same injury pattern using 2 different fixation methods.

In both groups, significant increase in ICP was observed within first 24-hour postoperative period. ACS is associated with insufficient microcirculation at the extremity. Pathogenetic mechanisms underlying this inadequate microcirculation are linked to increased pressure within non-elastic soft tissue compartment enclosed by fascia and bone. ${ }^{[3,5,11]}$ Therefore, ICP may be elevated due to increase in contents of compartment (e.g., as result of bleeding or edema) following fracture of the tibia. Furthermore, traction and manipulation associated with external fixation and tibial nailing during surgery may increase ICP. It has been reported that ICP increases as consequence of further tissue damage related to manipulation and longitudinal traction that occurs during tibial nailing procedure. ${ }^{[3,14]}$ Similar mechanism has been demonstrated in patients after placement of spanning external fixators. Longitudinal traction has been shown to increase ICP in highenergy plateau fractures. ${ }^{[24]}$ In the present study, we observed gradual decrease in ICP after 24 hours in both groups. This decrease may be attributed to resolution of edema and reperfusion of the compartment in fixed tibial fracture. ${ }^{[15,16]}$ In our previous study, we found similar results: ICP values of rabbits who underwent open and closed tibial fractures significantly decreased during second postoperative 24-hour period. ${ }^{[22]}$

In our opinion, the most valuable result of the present study is significant decrease in ICP at postoperative $30^{\text {th }}, 36^{\text {th }}$, and $42^{\text {nd }}$ hours in ICF group in comparison with IMP group. For transosseous fixation, K-wires are key components of llizarov device. K-wires can be considered slender beams that are subjected to transverse loading after being pretensioned axially and fixed to a support. K-wires are passed through the skin, and sometimes the muscles, multidirectionally to connect external fixator to the bone. ${ }^{[12,13,25,26]}$ Ilizarov external fixation produces trampoline effect because of highly tensioned wires supported circumferentially. ${ }^{[5]}$ Dynamic cleavage may occur due to trampoline effect of K-wires in all intercompartmental spaces (subcutaneous, fascial, muscular, and periosteal tissue). We think that drop in ICP may be due to increased serous drainage through pin tract during early postoperative period. K-wires passing through the skin make up the pin tract, and they act as openings (similar to a pop-up window) from the bone, muscle, and tissue compartments to the outside environment. In normal physiological tissue, the skin has typical tonus and elasticity, which means that it does not permit drainage through the skin. ${ }^{[12,27]}$ Immediately after bone fracture, combination of hematoma, edema, and extravasation of extracellular fluid occur at injury site. ${ }^{\left[{ }^{11]}\right.}$ During this period, swelling and edema are observed in the injured soft tissue compartment. In addition, the skin becomes edematous and non-elastic in nature. Thus, percutaneous drainage via $\mathrm{K}$-wires from tissue compartment to the outside may be result of the skin losing its elasticity. This drainage of extravasated fluid may be similar to subcutaneous fasciotomy. Furthermore, K-wires are not passed through just I compartment; they pass through almost all compartments. In this regard, serous drainage may be considered advantageous in reducing ICP. Therefore, llizarov circular fixation may provide additional decompression in all compartment of the lower leg.

Pin site must be kept clean to avoid infection of pin tract. Pin tract infection may cause loosening of the pin, which requires pin removal. ${ }^{[28]}$ In previous studies, increases in ICP have been noted with application of spanning external fixator. ${ }^{[24,29]} \mathrm{How}-$ ever, only 2 or 3 unilateral percutaneous Schanz pins were used for spanning of external fixators. Therefore, effect of drainage through Schanz pins can be ignored in the case of spanning external fixator. Although we did not encounter any drainage or hematoma on the edge of the K-wires during ICP application or within the first 24 hours of follow-up, with increased swelling and hematoma, drainage began to appear in second 24-hour period. We believe that lower ICP values of ICF group in second 24 hours were result of this change.

In this study, the fractured tibias in Group 2 were fixated with a 2-mm K-wire at intramedullary location in closed fashion. This method may be similar to flexible intramedullary nailing of long bone fractures. In recent studies, ${ }^{[20,30]}$ flexible intramedullary nailing of long bone fractures has been shown to have high risk for development of ACS in pediatric population. The reason may be soft-tissue trauma caused by multiple attempts to reduce the fracture and pass the nail.

The present study has several limitations. First of all, num- 
ber of animals used to determine effects of fracture on ICP profile was limited. Second, we used 2-mm K-wire as an intramedullary nail, rather than locking intramedullary nail, and IMP used has weaker stabilizing force on fractured bone fragments. Therefore, IMP was unlike modern intramedullary nails, which have additional locking holes that provide torsional stability to fracture. However, we did not have the opportunity to apply the implant type used in human tibia. Third, at middle region of tibia, tibia and fibula become fused in rabbits, and fracture was created at a site that is atypical for human fractures. Accordingly, clinical study that involves similar type of fracture with larger cohort will be needed to evaluate ICP values of fractures fixed with ICF versus IMP.

Clinical message of the current study is that ICF can be considered a surgical alternative to minimize serious risk of compartment syndrome in cases such as large hematoma with multiple fractures, extensive soft tissue damage and skin edema, or when patient cannot adapt to elevation. ICF can be definitive treatment option in such kind of complicated fracture. It is generally accepted that IMN is optimal choice for simple fracture. Furthermore, process of removal of ICF is less invasive than for IMN. Possible pin tract infection is more tolerable problem compared with detrimental risk of compartment syndrome.

\section{Conclusion}

ICP values of fractures fixed with ICF were lower than those of fractures fixed with IMP at the first postoperative 24 hours. These results indicate that ICF in tibial fracture provides additional decompression in the anterior compartment. This decrease in ICP may be related to serous drainage from the compartment to outside of the body via the Kwires in postoperative period. Therefore, ICF technique may be preferable for tibial fractures with risk for compartment syndrome. Since animal models may not completely reflect clinical course in humans, our results should be compared with the existing literature.

\section{Acknowledgments}

This project was funded by the Harran University Scientific Research Coordination Committee (20II/2/II43). Animal research ethics committee approval number: B.30.2. $\mathrm{H}$ RU.0.05.07.00/270-2010/4I.

The authors declare that they have no relevant financial involvement with any commercial organization with direct financial interest in the subject or materials discussed in this manuscript.

\section{Conflict of interest: None declared.}

\section{REFERENCES}

1. McQueen MM, Christie J, Court-Brown CM. Acute compartment syn- drome in tibial diaphyseal fractures. J Bone Joint Surg Br 1996;78:95-8.

2. Giannoudis PV, Tzioupis C, Pape HC. Early diagnosis of tibial compartment syndrome: continuous pressure measurement or not? Injury 2009; 40:341-2. Crossre.

3. Templeman DC, Anglen JO, Schmidt AH. The management of complications associated with tibial fractures. In: Azar FM, O'Connor MI, editors. Instructional course lectures, Vol. 58. Section 1 Trauma. First ed. American Academy of Orthopaedic Surgeons 6300 North River Road Rosemont, IL P. 2009;47-60.

4. Ojike NI, Roberts CS, Giannoudis PV. Compartment syndrome of the thigh: a systematic review. Injury 2010;41:133-6. Crossret

5. Rudloff MI. Fractures of lower extremity. In: Canale ST, Beaty JH, editors. Campbell's operative orthopaedics, Vol. 3. Chapter:54. 12th ed. Mosby- Elsevier, Philadelphia 2013.p. 2618-720. Crossree

6. Garner MR, Taylor SA, Gausden E, Lyden JP. Compartment syndrome: diagnosis, management, and unique concerns in the twenty-first century. HSS J 2014;10:143-52. Crossret

7. Djahangiri A, Garofalo R, Chevalley F, Leyvraz PF, Wettstein M, Borens $\mathrm{O}$, et al. Closed and open grade I and II tibial shaft fractures treated by reamed intramedullary nailing. Med Princ Pract 2006;15:293-8. Crossre

8. Ertürk C, Altay MA, Bilge A, Altay N, Işikan UE. Do additional intramedullary elastic nails improve the results of definitive treatment with external fixation of open tibia fractures? A prospective comparative study. Orthop Traumatol Surg Res 2013;99:208-15. Crossre

9. Ramos T, Eriksson BI, Karlsson J, Nistor L. Ilizarov external fixation or locked intramedullary nailing in diaphyseal tibial fractures: a randomized, prospective study of 58 consecutive patients. Arch Orthop Trauma Surg 2014;134:793-802. Crossre

10. Oztürkmen Y, Karamehmetoğlu M, Karadeniz H, Azboy I, Caniklioğlu M. Acute treatment of segmental tibial fractures with the Ilizarov method. Injury 2009;40:321-6. Crossre

11. Trafton PG. Tibial shaft fractures. In: Browner BD, Jupiter JB, Levine AM, Trafton PG, and Krettek C. eds. Skeletal Trauma. Vol. 2, Chapter: 58. Fourth ed. Copyright (C W. B. Saunders Company; 2009.p. 2319-451.

12. Ilizarov GA. The tension-stress effect on the genesis and growth of tissues. In: Green S (Ed) Transosseus osteosynthesis. Theoretical and clinical aspects of the regeneration and growth of tissue. Springer-Verlag Berlin 1992. p. 137-255. Crossre

13. Solomin LN. The basic principles of external fixation using the Ilizarov device (eds). Springer Verlag, Milan, Berlin, Heidelberger, New York 2008. p. 1-128.

14. Tischenko GJ, Goodman SB. Compartment syndrome after intramedullary nailing of the tibia. J Bone Joint Surg Am 1990;72:41-4. Crossrel

15. Tornetta P, French BG. Compartment pressures during nonreamed tibial nailing without traction. J Orthop Trauma 1997;11:24-7. Crossref

16. Nassif JM, Gorczyca JT, Cole JK, Pugh KJ, Pienkowski D. Effect of acute reamed versus unreamed intramedullary nailing on compartment pressure when treating closed tibial shaft fractures: a randomized prospective study. J Orthop Trauma 2000;14:554-8. Crossre

17. Mullett H, Al-Abed K, Prasad CV, O'Sullivan M. Outcome of compartment syndrome following intramedullary nailing of tibial diaphyseal fractures. Injury 2001;32:411-3. Crossre

18. Kutty S, Laing AJ, Prasad CV, McCabe JP. The effect of traction on compartment pressures during intramedullary nailing of tibial-shaft fractures. A prospective randomised trial. Int Orthop 2005;29:186-90. Crossre.

19. Duan X, Al-Qwbani M, Zeng Y, Zhang W, Xiang Z. Intramedullary nailing for tibial shaft fractures in adults. Cochrane Database Syst Rev 2012. Crossre

20. Pandya NK, Edmonds EW, Mubarak SJ. The incidence of compartment syndrome after flexible nailing of pediatric tibial shaft fractures. J Child Orthop 2011;5:439-47. Crossret

21. Ertürk C, Altay MA, Özardali İ, Altay N, Çeçe H, Işikan UE. The effect 
of extracorporeal shockwaves on cartilage end-plates in rabbits: a preliminary MRI and histopathological study. Acta Orthop Traumatol Turc 2012;46:449-54. Crossret

22. Altay MA, Ertürk C, Altay N, Oztürk IA, Baykara I, Sert C, et al. Comparison of intracompartmental pressures in a rabbit model of open and closed tibial fractures: an experimental study. Bone Joint J. 2013;95:1114. Crossre

23. Atesalp AS, Yurttas Y, Kose O, Demiralp B, Yildiz C, Kurklu M, et al. Effects of hyperbaric oxygen therapy on rabbit skeletal muscle during extremity lengthening. Arch Orthop Trauma Surg 2009;129:13-20.

24. Egol KA, Bazzi J, McLaurin TM, Tejwani NC. The effect of knee-spanning external fixation on compartment pressures in the leg. J Orthop Trauma 2008;22:680-5. Crossret

25. Gessmann J, Baecker H, Jettkant B, Muhr G, Seybold D. Direct and indirect loading of the Ilizarov external fixator: the effect on the interfragmentary movements and compressive loads. Strategies Trauma Limb Reconstr 2011;6:27-31.
26. Zamani AR, Oyadiji SO. Analytical modelling of Kirschner wires in Ilizarov circular external fixator as pretensioned slender beams. J R Soc Interface 2009;6:243-56. Crossret

27. Barnea Y, Gur E, Amir A, Leshem D, Zaretski A, Miller E, et al. Delayed primary closure of fasciotomy wounds with Wisebands, a skin- and soft tissue-stretch device. Injury 2006;37:561-6. Crossre]

28. Ertürk C, Çağman B, Altay MA, Işıkan UE. The use of Ender nail in intertrochanteric fractures supported with external fixation. Ulus Travma Acil Cerrahi Derg 2011;17:407-12. Crossree

29. Stark E, Stucken C, Trainer G, Tornetta P 3rd. Compartment syndrome in Schatzker type VI plateau fractures and medial condylar fracturedislocations treated with temporary external fixation. J Orthop Trauma 2009;23:502-6. Crossre

30. Blackman AJ, Wall LB, Keeler KA, Schoenecker PL, Luhmann SJ, O'Donnell JC, et al. Acute compartment syndrome after intramedullary nailing of isolated radius and ulna fractures in children.J Pediatr Orthop 2014;34:50-4.

\section{DENEYSEL ÇALIŞMA - ÖZET}

\section{Tibia cisim kırıklarında iki farklı cerrahi yöntemin kompartman basıncı üzerine etkisi:} Tavşan modelinde deneysel bir çalışma

\section{Dr. Cemil Ertürk, ${ }^{1 *}$ Dr. Mehmet Akif Altay, ${ }^{1}$ Dr. Nuray Altay, ${ }^{2}$ Dr. İbrahim Avşin Öztürk, ${ }^{1}$ \\ Dr. İslam Baykara, ${ }^{1}$ Dr. Cemil Sert, ${ }^{3}$ Dr. Uğur Erdem Işıkan ${ }^{1}$}

${ }^{1}$ Harran Üniversitesi Tıp Fakültesi, Ortopedi ve Travmatoloji Anabilim Dalı, Şanlıurfa

${ }^{2}$ Harran Üniversitesi Tıp Fakültesi, Anesteziyoloji ve Reanimasyon Anabilim Dalı, Şanlıurfa

${ }^{3}$ Harran Üniversitesi Tıp Fakültesi, Biyofizik Anabilim Dalı, Şanlıurfa

AMAÇ: Kompartman içi basınç (KiB) monitarizasyonu özellikle tibia cisim kırıklarının intramedüller çivilemesinden sonra sıkça kullanılan bir izlem yöntemidir. Ilizarov sirküler fiksatör (ICF) ile tespit yapılan tibia kırıklarındaki KiB değerlerinin intramedüller telleme (iMT) ile yapılanlardan daha düşük olabileceği öngörüldü. Bu çalışmada, ICF ve IMT ile tespit yapılan tibia kırıklarında KiB değerleri karşılaştıııldı.

GEREÇ VE YÖNTEM: Yirmi Yeni Zelenda Beyaz tavşanları rastgele ICF (Grup I) ve IMT (Grup 2) olmak üzere iki gruba ayrıldılar. Anestezi altında tavşanların sağ tibialarının üst yarıında kırık oluşturuldu. Tibia kırıkları Grup I'de iCF, Grup 2'de IMT ile tespit edildi. Kompartman içi basınç değerleri 48 saat boyunca altışar saat arayla ölçüldü.

BULGULAR: Kompartman içi basınç değerlerinde her iki grup içinde önemli farklar vardı $(p<0.00$ I). Ayrıca, her iki grupta KiB değerleri ameliyat sonra ilk 24 saatte önemli derecede artarken, ikinci 24 saatte azalmıştı. En önemlisi de, ICF grupta KiB değerleri IMT gruptakine göre, 30, 36 ve 42. saatlarda önemli derecede düşüktü $(p<0.05)$.

TARTIŞMA: Tespitten 24 saat sonra, ICF grubundaki KiB değerleri IMT'ye göre daha düşüktü. Bu sonuçlar tibia kırıklarında iCF kullanımının ön kompartmanda ek dekompresyon sağladığını göstermektedir. Bu bulguların ışı̆ında, iCF uygulaması kompartman sendromu riski taşıyan yüksek riskli tibia kırıkların tedavisinde tercih edilebilir.

Anahtar sözcükler: Akut kompartman sendromu; illizarov eksternal fiksatör; intramedüller çivi tespiti; kompartman içi basınç monitarizasyonu; tibia kırıkları.

Ulus Travma Acil Cerrahi Derg 2017;23(2):85-90 doi: 10.5505/tjtes.2016.82177 